\title{
Effect of surgical and immunocastration of male cattle on instrumental measure of tenderness and dissected lean
}

\author{
B. W. Moss ${ }^{1}$, N. F. S. Gault ${ }^{1}$, D. J. Kilpatrick² $\ddagger$, W. McLauchlan ${ }^{3}$, W. J. McCaughey ${ }^{4}$ and C. Moore \\ 'Department of Food and Agricultural Chemistry, The Queen's University of Belfast, Newforge Lane, Belfast BT9 5PX \\ ${ }^{2}$ Department of Biometrics, The Queen's University of Belfast, Newforge Lane, Belfast BT9 5PX \\ ${ }^{3}$ Enniskillen College of Agriculture, Castle Archdale Experimental Husbandry Farm, Department of Agriculture for \\ Northern Ireland, Irvinestown, Co. Fermanagh BT94 1PT \\ ${ }^{4}$ Veterinary Science Division, Department of Agriculture for Northern Ireland, Stoney Road, Belfast BT4 3SD \\ ${ }^{5}$ Greenmount College of Agriculture and Horticulture, Department of Agriculture for Northern Ireland, 22 Greenmount \\ Road, Antrim BT41 4PU
}

\section{Introduction}

It is well documented that bulls have faster growth rates, better food efficiency and produce leaner carcasses than steers (Field, 1971; Seideman, Cross, Oltjen and Schanbacher, 1982). The problems of using bulls instead of steers, however, include those relating to more aggressive behaviour both on the farm and between farm slaughter (Price and Tennessen, 1981; Gregory and Ford, 1983) often resulting in dark cutting beef or dark firm and dry (DFD) meat. Although the higher incidence of DFD meat in bulls is generally attributed to their aggressive nature (Price and Tennessen, 1981), the eventual meat quality depends also on intrinsic factors. Sex differences in muscle fibre type have been reported (Ockerman, Jaworek, Van Stavern, Parrett and Pierson, 1984; Seidman, Crouse and Cross, 1986) and muscle fibre type distributions have been related to both ultimate $\mathrm{pH}\left(\mathrm{pH}_{\mathrm{u}}\right)$ (Talmant, Monin, Briand, Dadet and Briand, 1986) and meat tenderness (Hunt and Hedrick 1977; Calkins, Dutson, Smith, Carpenter and Davis, 1981).

Literature reports of sex differences in meat tenderness are conflicting, with some indicating meat from bulls is less tender meat than from steers (Seidman et al., 1982; Jeremiah, Newman, Tong and Gibson, 1988a and b), whilst others suggest no significant sex differences (Arthaud, Mandigo, Koch and Kotula, 1977). Some of these discrepancies may have arisen as a consequence of the more rapid drop

\footnotetext{
† Also member of staff of Food and Agricultural Chemistry, Research Division, Department of Agriculture for Northern Ireland, Newforge Lane, Belfast BT9 5PX.

$\ddagger$ Also member of staff of Biometrics Division, Department of Agriculture for Northern Ireland, Newforge Lane, Belfast BT9 $5 P X$.
}

in temperature in leaner carcasses during chilling post mortem (Dransfield, Nute and Francombe, 1984). This may be sufficiently rapid to induce cold shortening (i.e. in general a drop to below $10^{\circ} \mathrm{C}$ in $10 \mathrm{~h}$ post mortem) and consequent toughening of the meat. There is also evidence, however, which indicates that rapid chilling which has not induced conditions for cold shortening can also result in toughening of the meat (Lochner, Kauffman and Marsh, 1980).

Most studies relating to sex differences have compared entire males (bulls) with total castrates (steers), and there is little information on other methods of castration in relation to meat quality. Robertson, Fraser, Innes and Jones (1982) suggested that immunocastration of bulls produced docile behavour and superiority in production compared with steers. Mohan Raj, Moss, McCaughey, McLaughlan, McGaughey and Kennedy (1991a) reported that in general total castration produced more profound physiological changes than either vasectomy or immunocastration. Vasectomized bulls showed greater homosexual activity than bulls under both controlled pre-slaughter handling and when mixed with strange animals (Mohan Raj, Moss, McCaughey, McLaughlan, Kilpatrick and McGaughey, 1991b) and had higher ultimate $\mathrm{pH}$ values $\left(\mathrm{pH}_{\mathrm{u}}\right.$ ) (Mohan Raj et al., 1991a). The anaerobic fibre ratio (Hunt and Hedrick, 1977) of vasectomized bulls was intermediate between bulls and steers whilst that of immunocastrates was closer to that of bulls (Mohan Raj et al., 1991a). Pietersen, Bruwer and Naudé (1992a); and Pietersen, Bruwer, Smit, Bok and Naudé (1992b) in studying sex differences, further classified entire males according to their masculinity based on conformation of the forequarter. In these studies, bulls classified as more masculine had a higher meat proportion (Pietersen et al., 1992a), and differences in meat quality indicators were found in 
the $m$. splenius but not in the $m$. longissimus thoracis (Pietersen et al., 1992b).

The aim of the studies reported here was to extend those of Mohan Raj et al. (1991a) to carcass quality and meat quality, particularly meat tenderness. A further aim was to investigate the suggestion of Moss (1992) that differences in sex status might be used to provide a model for the study of the complex interactions between leanness, stress sensitivity and meat quality.

\section{Material and methods}

The experiment involved a total of 226 animals reared at two locations (farm 1 and farm 2) and consisted of three replicates at farm 1 (61 animals) and six replicates at farm 2 (162 animals of which 142 were studied for carcass and meat quality). The animals at farm 1 were obtained from a single suckler herd and were predominantly Limousin and Charolais out of Aberdeen Angus $X$ Friesian cows. At farm 2, the animals were Simmental and Limousin crosses out of Friesian, Holstein or Friesian $\times$ Holstein cows.

The experiment consisted of four sex types: entire males (EB); traditional surgical castration at 2 to 3 months of age (steers S); and immunocastrated (IB); and vasectomized animals (VB). Immunocastration was performed following the technique of Fraser, Gunn, Jeffcoate and Holland (1974) using synthetic luteinizing hormone releasing factor (LHRF supplied by Hoescht AG. Frankfurt, Germany) as the immunogen with a first injection at around 3 months of age followed by a booster 7 weeks later. Vasectomy was carried out according to the method of McCaughey and Martin (1980).

The animals were weaned at grass between 215 to 240 days of age and then housed. During housing animals were kept in groups of 5 (years 1 and 2) or 6 (year 3) (farm 1) or groups of 7 (years 1 and 2) or 6 (year 3) (farm 2), and given silage ad libitum supplemented with concentrates. Feeding and husbandry procedures for year 1 of this experiment have been described in detail by Mohan Raj et al. (1991a and b).

\section{Pre-slaughter handling}

To obtain empty body weights animals were fasted for $18 \mathrm{~h}$ at 1 to 2 days prior to slaughter. On the morning of slaughter the animals were loaded on to the lorry between 07.00 and $08.00 \mathrm{~h}$, each group being kept separate during transport. In year 1 of the study, animals from farm 1 and one replicate from farm 2, were sent to abattoir $A$, the second replicates from farm 2 being transported a distance of $75 \mathrm{~km}$ to abattoir B (further details given by Mohan Raj et al. 1991a and b). Except for year 1, all animals were sent to the same abattoir (abattoir A), a distance of $80 \mathrm{~km}$ for farm 1 and $20 \mathrm{~km}$ for farm 2. Animals were slaughtered within $60 \mathrm{~min}$ of arrival at the abattoir.

\section{Collection of samples at slaughter and post mortem}

The carcasses were placed in the chill room of the abattoir $1 \mathrm{~h}$ after slaughter and in year 1 and 2 the temperature of two carcasses was measured in the deep leg using a Squirrel data logger (Grant Instruments, Cambridge) to assess the likelihood of cold shortening occurring. In year 3 , measurements to monitor chilling rate were made on eight carcasses selected at random.

At 24 h post mortem the sides were quartered between the 10 th and 11 th ribs, fat measurements were taken and a forerib joint was removed from each carcass as described by Kempster, Cook and Smith (1980). A slice of longissimus dorsi (LDu) $3 \mathrm{~cm}$ thick at the 11th rib was dissected out $24 \mathrm{~h}$ post mortem and used for colour measurements. Samples of LDu were taken for sarcomere length measurements 24 or $48 \mathrm{~h}$ post mortem. After ageing the forerib at $1^{\circ} \mathrm{C}$ for 7 days post mortem, a further sample of LDu was taken for cooking loss and texture measurements. The forerib joint was retained for dissection into lean, fat and bone. The quantity of lean previously removed for analysis was added back prior to calculation.

\section{Ultimate $p H$}

A 1-g sample of longissimus dorsi muscle was removed from the posterior portion of the forerib joint (i.e. position of quartering) $48 \mathrm{~h}$ post mortem. The sample was homogenized with $10 \mathrm{ml}$ of $5 \mathrm{mmol} / 1$ iodoacetate buffer solution ( $\mathrm{pH} \quad 7 \cdot 0)$ containing $150 \mathrm{mmol} / 1$ potassium chloride (Bendall, 1973) and the $\mathrm{pH}$ of the homogenate measured.

\section{Cooking loss and texture measurement}

A $35-$ to $40-\mathrm{mm}$ thick slice was cut transverse to the muscle fibre direction from the posterior end of the forerib joint 7 days post mortem. The $\mathrm{pH}$ of the slice was measured using a Ross spear tip combination electrode (catalogue no. SC8163) attached to an Orion Research digital $\mathrm{pH} / \mathrm{mv}$ meter (Model 611). After allowing the electrode to equilibrate, the $\mathrm{pH}$ of the muscle slice was noted ( $\mathrm{pH} 7$ days). The steak slices were weighed and then placed in a polythene bag and cooked by placing in a water bath at $75^{\circ} \mathrm{C}$ for $50 \mathrm{~min}$. After this time the slices were cooled in an ice-water bath for 30 to $40 \mathrm{~min}$. Excess liquid was removed by gently padding the slices with absorbent paper towelling, and the slices then reweighed to calculate cooking losses. These cooked samples were stored at $4^{\circ} \mathrm{C}$ for no longer than $24 \mathrm{~h}$ prior to analysis on the Instron. 
The Instron (model no. 6021) was calibrated for a compression test using a $1 \mathrm{kN}(100 \mathrm{~kg})$ load cell to measure force in the range 0 to $20 \mathrm{~kg}$. A WarnerBratzler shear device was fitted and the test speed set to $100 \mathrm{~mm} / \mathrm{min}$. The end of test conditions were set to recognize a peak once $40 \%$ fall off was obtained. Ten 13-mm diameter cores of the cooked meat were removed from each slice along the axis of the muscle fibres using a cork borer. Each core was inserted in the Warner-Bratzler shear device so that it cut across the muscle fibres. The results obtained as $\mathrm{kg}$ force required to shear the cooked meat were recalculated as force per unit cross-sectional area $\left(\mathrm{kg} / \mathrm{cm}^{2}\right)$.

Determination of sarcomere length

At 24 to $48 \mathrm{~h}$ post mortem, small pieces of raw longissimus dorsi of dimensions approximately $10 \mathrm{~mm}$ $\times 2 \mathrm{~mm} \times 2 \mathrm{~mm}$, were dissected out so that the muscle fibres ran parallel to the long axis of the sample. These dissected samples were fixed in 5\% gluteraldehyde solution containing $0.1 \mathrm{~mol} / \mathrm{dm}^{3}$ $\mathrm{Na}_{2} \mathrm{HPO}_{4}$, at $\mathrm{pH} 7.2$ at a temperature of not more than $10^{\circ} \mathrm{C}$ for $4 \mathrm{~h}$. The samples were then washed in buffered sucrose solution $\left(0.2 \mathrm{~mol} / \mathrm{dm}^{3}, \mathrm{pH} 7 \cdot 2\right)$ (Koolmees, Korteknie and Smulders, 1986). The

Table 1 Effect of surgical and immunocastration of bulls on meat quality

\begin{tabular}{|c|c|c|c|c|c|}
\hline & $\begin{array}{l}\mathrm{pH}_{\mathrm{u}} \\
48 \mathrm{~h}\end{array}$ & $\begin{array}{l}\text { arcomere } \\
\text { length } \\
(\mu \mathrm{m})\end{array}$ & $\begin{array}{c}\text { Cooking } \\
\text { losst } \\
(\mathrm{g} / \mathrm{kg})\end{array}$ & $\begin{array}{c}\mathrm{pH}_{\mathrm{u}}+ \\
7 \text { days }\end{array}$ & $\begin{array}{l}\text { Instron } \\
\text { sheart } \\
\left(\mathrm{kg} / \mathrm{cm}^{2}\right)\end{array}$ \\
\hline \multicolumn{6}{|l|}{ Year } \\
\hline 1 & $5 \cdot 67$ & NA & $\mathrm{NA}$ & NA & 3.96 \\
\hline 2 & 5.66 & NA & $242 \cdot 0$ & $5 \cdot 47$ & $4 \cdot 10$ \\
\hline 3 & 5.69 & $1 \cdot 802$ & $243 \cdot 2$ & $5 \cdot 45$ & $4 \cdot 22$ \\
\hline s.e.d. & 0.031 & 0.015 & $6-20$ & $0 \cdot 011$ & $0 \cdot 210$ \\
\hline \multicolumn{6}{|l|}{ Location } \\
\hline Farm 1 & 5.61 & 1.79 & 232.9 & 5.42 & $3 \cdot 82$ \\
\hline Farm 2 & 5.73 & $1 \cdot 81$ & $252 \cdot 6$ & $5 \cdot 49$ & $4 \cdot 37$ \\
\hline s.e.d. & 0.025 & 0.031 & $6 \cdot 44$ & $0 \cdot 112$ & 0.172 \\
\hline Significance & $* * *$ & & $* *$ & $* * *$ & $* * *$ \\
\hline \multicolumn{6}{|l|}{ Sex } \\
\hline Immunized & $5 \cdot 68^{\mathrm{ab}}$ & 1.82 & $243 \cdot 7^{\mathrm{ab}}$ & $5 \cdot 46^{b}$ & $4 \cdot 22^{\mathrm{b}}$ \\
\hline Vasectomized & $5.72^{\mathrm{b}}$ & $1 \cdot 80$ & $246 \cdot 5^{\mathrm{ab}}$ & $5 \cdot 47^{b}$ & $4 \cdot 41^{b}$ \\
\hline Entire & $5 \cdot 68^{\mathrm{ab}}$ & 1.77 & $251 \cdot 5^{\mathrm{b}}$ & $5 \cdot 46^{\mathrm{b}}$ & $4 \cdot 32^{\mathrm{b}}$ \\
\hline Steer & $5 \cdot 61^{\mathrm{a}}$ & 1.82 & $229 \cdot 6^{a}$ & $5 \cdot 42^{\mathrm{a}}$ & $3 \cdot 42^{\mathrm{a}}$ \\
\hline s.e.d. & 0.035 & 0.044 & $9 \cdot 10$ & 0.017 & $0 \cdot 243$ \\
\hline Significance & $* *$ & & $* *$ & $* * *$ & $* * *$ \\
\hline \multicolumn{6}{|l|}{ Interactionsf } \\
\hline Year/location & $*$ & & & $* *$ & \\
\hline
\end{tabular}

a, b Means with common superscripts are not significantly different $(P>0.05)$.

$\mathrm{NA}=$ Not applicable, the data were not collected for these years.

$\uparrow$ Measurement made 7 days post mortem after storage of samples at $1^{\circ} \mathrm{C}$.

$\ddagger$ Year/sex,location/sex, year/location/sexinteractions were not significant $(P>0.05)$. samples were stored in sucrose solution until required (a maximum of up to 4 days) for measurement by laser diffraction.

Fibre bundles were then teased from each fixed sample and placed on a microscope slide in a drop of buffered sucrose solution. The diffraction pattern was assessed by exposing the sample to a $4.0 \mathrm{~mW}$ helium neon gas laser beam of wavelength $632.8 \mathrm{~nm}$. Sarcomere lengths were calculated according to the formula used by Cross, West and Dutson (1981).

\section{Statistical analysis}

The data were subjected to analysis of variance to test for the main effects of year, location and sex and their interactions.

\section{Results}

\section{Measure of tenderness}

There were no differences between years for any of the tenderness measurements (Table 1). The $\mathrm{pH}$ values measured 7 days post mortem were on average $0.2 \mathrm{pH}$ units lower than those measured $48 \mathrm{~h}$ post mortem which is probably a reflexion of the difference in technique used (probe $v$. homogenization). There was a significant correlation of 0.50 between the two sets of $\mathrm{pH}$ values $(P<0.001)$. The $\mathrm{pH}_{\mathrm{u}} 48 \mathrm{~h}$ values in the steers were $0.07 \mathrm{pH}$ units lower than the other male types being significantly lower than the vasectomized bulls $(P<0.05)$. The $\mathrm{pH}$ values taken 7 days post mortem were significantly lower for steers than the other male types $(P<0.05)$.

Instron values of the steers were significantly lower than those for the other male types which were similar $(P<0.001)$. Cooking loss was lower for the steers than for the other male types although this was only significantly lower for the entire bulls $(P<0.05)$. There were no significant sex differences in sarcomere length.

There were significant $(P<0.01)$ differences between locations with $\mathrm{pH}_{\mathrm{u}} 48 \mathrm{~h}, \mathrm{pH}_{\mathrm{u}} 7$ days, cooking loss and Instron values all being lower for farm 1 than for farm 2 . This may have reflected differences in genetic background as well as production systems between the two production locations.

\section{Sample joint composition}

The amount of fat dissected from the forerib joint was significantly $(P<0.05)$ lower, and the bone preparation significantly higher $(P<0.001)$ in year 3 than in the other 2 years (Table 2). The amount of dissected lean was significantly $(P<0.01)$ lower and bones significantly $(P<0.001)$ higher in the farm 2 cattle than in the farm 1 cattle. 
Table 2 Effect of surgical and immunocastration on the carcass composition based on dissection of the forerib joint

\begin{tabular}{|c|c|c|c|}
\hline & $\begin{array}{c}\text { Forerib } \\
\text { lean } \\
(\mathrm{g} / \mathrm{kg})\end{array}$ & $\begin{array}{c}\text { Forerib } \\
\text { fat } \\
(\mathrm{g} / \mathrm{kg})\end{array}$ & $\begin{array}{c}\text { Forerib } \\
\text { bones } \\
(\mathrm{g} / \mathrm{kg})\end{array}$ \\
\hline \multicolumn{4}{|l|}{ Year } \\
\hline 1 & $537 \cdot 4$ & $272 \cdot 6$ & $190 \cdot 0$ \\
\hline 2 & $539 \cdot 6$ & $267 \cdot 4$ & $193 \cdot 0$ \\
\hline 3 & 534.9 & $255 \cdot 2$ & 209.8 \\
\hline s.e.d. & 4.94 & $5 \cdot 3$ & 3.69 \\
\hline Significance & & * & $* * *$ \\
\hline \multicolumn{4}{|l|}{ Location } \\
\hline Farm 1 & 543.5 & $265 \cdot 6$ & $190 \cdot 9$ \\
\hline Farm 2 & $531 \cdot 1$ & $264 \cdot 6$ & $204 \cdot 3$ \\
\hline s.e.d. & $4 \cdot 04$ & $4 \cdot 34$ & $3 \cdot 01$ \\
\hline Significance & $* *$ & & $* * *$ \\
\hline \multicolumn{4}{|l|}{ Sex } \\
\hline Immunized & $549 \cdot 1^{c}$ & $253 \cdot 1^{\mathrm{c}}$ & $197 \cdot 8^{\mathrm{ab}}$ \\
\hline Vasectomized & $548 \cdot 0^{c}$ & $246 \cdot 1^{b c}$ & $205.9^{b}$ \\
\hline Entire & $564.9^{\mathrm{b}}$ & $238.9^{b}$ & $196 \cdot 1^{\mathrm{a}}$ \\
\hline Steer & $487 \cdot 2^{\mathrm{a}}$ & $322 \cdot 0^{a}$ & $190 \cdot 8^{\mathrm{a}}$ \\
\hline s.e.d. & $5 \cdot 71$ & $6 \cdot 14$ & $4 \cdot 26$ \\
\hline Significance & $* * *$ & $* * *$ & $* * *$ \\
\hline \multicolumn{4}{|l|}{ Interactions } \\
\hline Year/location & & $* *$ & $* *$ \\
\hline Year/sex & & $*$ & \\
\hline \multicolumn{4}{|l|}{ Location/sex } \\
\hline Year/location/sex & & & ** \\
\hline
\end{tabular}

$a, b, c$ Means with common superscripts are not significantly different $(P>0 \cdot 05)$.

There were significant sex differences in the dissected lean, fat and bones proportion. In all cases the steers had less lean and more fat than the other three male types, while the entire males had more lean and less fat than the immunized and vasectomized males. The amount of bones of the entire bulls was significantly lower than that of the vasectomized bulls $(P<0.05)$.

\section{Discussion}

Carcass quality and meat quality depend on the interaction between intrinsic and extrinsic factors. When comparing the two locations, the intrinsic factors are most likely to arise from genetic differences while the extrinsic factors are related to husbandry practices, and pre- or post-slaughter handling. The lack of differences in sarcomere length between locations suggest that post-slaughter chilling rate was not a major factor. Jeremiah, Tong and Gibson (1991) found that over the range 5.4 to 5.9 shear force values increased with increasing $\mathrm{pH}_{\mathrm{u}}$. The higher $\mathrm{pH}_{\mathrm{u}}$ and shear force at farm 2 in the present experiments are in line with this. Ultimate $\mathrm{pH}$ values generally increase with duration of stress pre-slaughter such as duration of journey and lairage. In the present experiments, the higher $\mathrm{pH}_{\mathrm{u}}$ values were associated with the group with shorter transport times, and intrinsic factors, such as muscle fibre type, may provide a more likely explanation for $\mathrm{pH}_{\mathrm{u}}$ differences.

Jeremiah et al. (1991) reported higher shear force values in halfbred Simmental than halfbred Charolais and Limousin. The higher shear force values recorded in carcasses from farm 2 may be explained by the Simmental crosses compared with Charolais crosses at farm 1 . These results, however, conflict with those of Cross, Schanbacher and Crouse (1984) who found less total collagen and more soluble collagen in meat from Simmental compared with Charolais. Thus the differences between farm 1 and farm 2 would appear to be a combination of both genetic factors and husbandry practices.

The sex differences in both carcass quality and meat quality follow a pattern in that, in general, the main statistically significant differences were between steers and the other three sex types, with only small differences between the latter. The incidence of DFD meat (defined as $\mathrm{pH}_{\mathrm{u}}>6.0$ ) was approximately $11 \%$ in both vasectomized bulls and entire bulls, with none in steers. The incidence of DFD in immunocastrates was only $2 \%$ which would support the previous reports of Robertson et al. (1982) of immunocastration resulting in more docile behaviour. The sex differences in $\mathrm{pH}_{\mathrm{u}}$ are in a similar order to those reported by Mohan Raj et al. (1991) i.e. vasectomized bulls $>$ immunocastrated bulls $>$ entire bulls > steers and might similarly be explained on the basis of muscle fibre type. Vasectomized animals appear to have a physiological type more prone to DFD.

The overall correlations between $\mathrm{pH}_{\mathrm{u}}$ and shear values in the present study (Table 3 ) are lower than those reported by Jeremiah et al. (1991). In the present study, sex differences in shear force would seem to be less explained by sarcomere length $(r=$ $0 \cdot 19, P<0.05)$ and more related to fat content $(r=$ $0.39, P<0.05)$. Smulders, Marsh, Swartz, Russell and Hoenecke (1990) showed that the relationship

Table 3 Correlations between meat quality parameters and dissection measurements

\begin{tabular}{lccc}
\hline \hline & $\begin{array}{c}\text { Forerib } \\
\text { lean } \\
(\mathrm{g} / \mathrm{kg})\end{array}$ & $\begin{array}{c}\text { Forerib } \\
\text { fat } \\
(\mathrm{g} / \mathrm{kg})\end{array}$ & $\begin{array}{c}\text { Forerib } \\
\text { bones } \\
(\mathrm{g} / \mathrm{kg})\end{array}$ \\
\hline $\mathrm{pH} 48 \mathrm{~h}$ & $0 \cdot 17^{*}$ & $-0 \cdot 20^{* *}$ & $0 \cdot 09$ \\
Shear force $\left(\mathrm{kg} / \mathrm{cm}^{2}\right)$ & $0 \cdot 28^{* * *}$ & $-0 \cdot 39^{* * *}$ & $0 \cdot 27^{* * *}$ \\
$\mathrm{pH}_{\mathrm{u}} 7$ days & $0 \cdot 16$ & $-0 \cdot 14$ & $0 \cdot 00$ \\
Cooking loss $(\mathrm{g} / \mathrm{kg})$ & $0 \cdot 11$ & $-0 \cdot 17^{*}$ & $0 \cdot 13$ \\
Sarcomere length $(\mathrm{\mu m})$ & $-0 \cdot 01$ & $0 \cdot 10$ & $-0 \cdot 16$ \\
\hline \hline
\end{tabular}


between sarcomere length and tenderness was greater in slow glycolysing muscles than in fast glycolysing muscles. The relationship between $\mathrm{pH}_{\mathrm{u}}$ and shear values has been shown to vary according to sex type (Jeremiah et al., 1991). The sex differences in tenderness and cooking loss are dependent on an interaction of a number of different factors and from the correlations obtained fat content would appear to be the most important. Underlying sex differences in intrinsic muscle properties such as fibre type (Mohan Raj et al., 1991a) or collagen (Cross et al., 1984) may be related to the influence of method of castration on testosterone levels. Mohan Raj et al. (1991b) postulated a possible relationship between pituitary/ adrenal function and testosterone to explain the aggressive nature and consequent high $\mathrm{pH}_{\mathrm{u}}$ values of vasectomized bulls.

Differences found in dissected lean are in line with previous studies with bulls being leaner than steers (Field, 1971). Immunocastration and vasectomy produced leaner carcasses than steers, but not quite as lean as entire bulls. However, there is some evidence from circulating antibody levels that immunocastration was not totally effective in all cases (W. I. McCaughey, personal communication) and thus some may be more similar to entire bulls. This would indicate that as far as leanness is concerned vasectomized bulls may be superior to immunocastrates. The greater homosexual activity and aggressive nature of vasectomized bulls (Mohhan Raj et al., 1991b) would counteract this.

In conclusion, total castration had a more profound effect on carcass and meat quality than vasectomy or immunocastration. However, further work is required on alternative methods of immunocastration and such studies may provide the basis to model relationships between leanness, stress sensitivity and meat quality.

\section{Acknowledgements}

The authors wish to thank Dr R. Humke, Hoechst AG for the gift of the initial supply of LHRF. They also thank G. Kirkpatrick, E. Tolland and R. Caldwell for technical assistance and sample collection. Dr S. J. McGaughey is thanked for his involvement in planning in the early stages of the experiment. The animal husbandry staff at Castle Archdale and Loughgall Experimental Husbandry Farms are thanked for their assistance.

\section{References}

Arthaud, V. H., Mandigo, R. W., Koch, R. M. and Kotula, A. W. 1977. Carcass composition, quality and palatibility attributes of bulls and steers fed different energy levels and killed at four ages. Journal of Animal Science 44: 53-64.
Bendall, J. R. 1973. Postmortem changes in muscle. In The structure and function of muscle. 2nd ed., vol. 2 (ed. G. H. Bourne), pp. 243-309. Academic Press, New York.

Calkins, C. R., Dutson, T. R., Smith, G. C., Carpenter, Z. L. and Davis, G. W. 1981. Relationships of fiber type composition to marbling and tenderness of bovine muscle. Journal of Food Science 46: 708-710.

Cross, H. R., West, R. L. and Dutson, T. R. 1981. Comparison of methods for measuring sarcomere length in beef semitendinosus muscle. Meat Science 5: 261-266.

Cross, H. R., Schanbacher, B. D. and Crouse, J. D. 1984. Sex, age and breed related changes in bovine testosterone and intramuscular collagen. Meat Science 10: 187-195.

Dransfield, E., Nute, G. R. and Francombe, M. A. 1984. Comparison of eating quality of bull and steer beef. Animal Production 39: 37-50.

Field, R. A. 1971. Effect of castration on meat quality and quantity. Journal of Animal Science 32: 849-858.

Fraser, H. M., Gunn, A., Jeffcoate, S. L. and Holland, D. T. 1974. Effect of active immunization to leutinizing hormone releasing hormone on serum pituitary gonadotropins, testes and accessory sex organs in the male rat. Journal of Endocrinology 63: 399-406.

Gregory, K. E. and Ford, J. J. 1983. Effects of late castration, zeranol and breed group on growth, feed efficiency and carcass characteristics of late maturing bovine males. Journal of Animal Science 56: 771-780.

Hunt, M. C. and Hedrick, H. B. 1977. Profile of fibre types and related properties of five bovine muscles. Journal of Food Science 42: 513-517.

Jeremiah, L. E., Newman, J. A., Tong, A. K. W. and Gibson, L. L. 1988a. The effects of castration, pre-slaughter stress and zerenol implants on beef. Part 1. The texture of loin steaks from bovine males. Meat Science 22: 83-101.

Jeremiah, L. E., Newman, J. A., Tong, A. K. W. and Gibson, L. L. 1988b. The effects of castration, pre-slaughter stress and zerenol implants on beef. Part 2. Cooking properties and flavour of loin steaks from bovine males. Meat Science 22: 103-121.

Jeremiah, L. A., Tong, A. K. W. and Gibson, L. L. 1991. The usefulness of muscle colour and $\mathrm{pH}$ for segregating beef carcasses into tenderness groups. Meat Science 30: 97-114.

Kempster, A. J., Cook, G. L. and Smith, R. J. 1980. The evaluation of a standardized commercial cutting technique for determining breed differences in carcase composition. Journal of Agricultural Science, Cambridge 95: 431-440.

Koolmees, P. A., Korteknie, F. and Smulders, F. J. M. 1986. Accuracy and utility of sarcomere length assessment by laser diffraction. Food Microstructure 5: 71-76.

Lochner, J. V., Kauffman, R. G. and Marsh, B. B. 1980. Early postmortem cooling rate and beef tenderness. Meat Science 4: 227-241.

McCaughey, W. J. and Martin, J. B. 1980. Preparation and use of teaser bulls. Veterinary Record 106: 119-121.

Mohan Raj, A. B., Moss, B. W., McCaughey, W. J., McLauchlan, W., McGaughey, S. J. and Kennedy, S. 1991a. Effects of surgical and immunocastration of beef cattle on meat colour, post-mortem glycolytic metabolites and fibre type distribution. Journal of the Science of Food and Agriculture 54: 111-126. 
Mohan Raj, A. B., Moss, B. W., McCaughey, W. J., McLauchlan, W., Kilpatrick, D. J. and McGaughey, S. J. 1991b. Behavioural response to mixing of entire bulls, vasectomised bulls and steers. Applied Animal Behaviour Science 31: 157-168.

Moss, B. W. 1992. Lean meat, animal welfare and meat quality. In The chemistry of muscle based foods (ed. D. E. Johnston, M. Knight and D. A. Ledward), Royal Society of Chemistry.

Ockerman, H. W., Jaworek, D., Van Stavern, B., Parrett, N. and Pierson, C. J. 1984. Castration and sire effects on carcass traits, meat palatability and muscle fibre characteristics in Angus Cattle. Journal of Animal Science 59: 981-990.

Pietersen, T., Bruwer, G. G. and Naudé, R. T. 1992a. Secondary sexual development (masculinity) of bovine males. 1. Influence on carcass composition, cutability, economic value and certain muscles. Meat Science 31: $435-450$.

Pietersen, T., Bruwer, G. G., Smit, M. C., Bok, W. and Naudé, R. T. 1992b. Secondary sexual development (masculinity) of bovine males. 2. Influence on certain meat quality characteristics. Meat Science 31: 451-462.
Price, M. A. and Tennessen, T. 1981. Pre-slaughter management and dark-cutting in the carcasses of young bulls. Journal of Animal Science 61: 205-208.

Robertson, I. S., Fraser, H. M., Innes, G. M. and Jones, A. S. 1982. Effect of the immunological castration on sexual and production characteristics in male cattle. Veterinary Record 111: 529-531.

Seideman, S. C., Cross, H. R., Oltjen, R. R. and Schanbacher, B. D. 1982. Utilization of the intact male for red meat production: a review. Journal of Animal Science 55: 826-840.

Seideman, S. C., Crouse, J. D. and Cross, H. R. 1986. The effect of sex condition and growth implants on bovine muscle fibre characteristics. Meat Science 17: 79-95.

Smulders, F. J. M., Marsh, B. B., Swartz, D. R., Russell, R. L. and Hoenecke, M. E. 1990. Beef tenderness and sarcomere length. Meat Science 28: 349-363.

Talmant, A., Monin, G., Briand, M., Dadet, M. and Briand, Y. 1986. Activities of metabolic and contractile enzymes in 18 bovine muscles. Meat Science 18: 23-40. 